\title{
Effect of prostaglandins on luteal function during early pregnancy in pigs
}

\author{
T. Wiesak*, M. G. Hunter and G. R. Foxcroft* \\ AFRC Research Group on Hormones and Farm Animal Reproduction, University of Nottingham, \\ School of Agriculture, Sutton Bonington, Loughborough LE12 3RD, UK
}

\begin{abstract}
Summary. Luteal cells were obtained by digestion of luteal tissue of cyclic (day 12) and early pregnant (days 12, 20 and 30) pigs. Suspensions of the dispersed luteal cells $\left(5 \times 10^{4}\right.$ cells $\left.\mathrm{ml}^{-1}\right)$ were incubated for $2 \mathrm{~h}$ in minimum essential medium (MEM) alone (control) and MEM with different concentrations of prostaglandin $\mathrm{F}_{2 \alpha}\left(\mathrm{PGF}_{2 \alpha}\right)$ and $\mathrm{PGE}_{2}\left(0 \cdot 01,0 \cdot 1,1,10,100\right.$ and $\left.1000 \mathrm{ng} \mathrm{ml}^{-1}\right)$ and luteinizing hormone (LH) 100 and $1000 \mathrm{ng} \mathrm{ml}^{-1}$, or with combinations of $\mathrm{LH}+\mathrm{PGF}_{2 u}$ and $\mathrm{LH}+\mathrm{PGE}_{2}$. Net progesterone production was measured in the incubation media by direct radioimmunoassay.

The overall response pattern of the luteal cells to exogenous hormones on day 12 of the oestrous cycle and pregnancy differed $(P<0.05)$ from treatment on day 20 and 30 of pregnancy. In general progesterone production was higher $(P<0.05)$ and the response to $\mathrm{PGF}_{2 \alpha}$ and $\mathrm{PGE}_{2}$ treatment was most obvious on day 12 of the oestrous cycle and pregnancy. Overall, $\mathrm{PGF}_{2 \alpha}$ stimulated progesterone production in a dosedependent manner $(P<0.05)$. The response to $\mathrm{PGE}_{2}$ was of a quadratic nature $(P<0.05)$ in which the lowest and the highest doses of $\mathrm{PGE}_{2}$ were associated with a greater production of progesterone than were the intermediate doses. Treatment of luteal cells with $\mathrm{PGF}_{2 \alpha}+\mathrm{LH}$ or $\mathrm{PGE}_{2}+\mathrm{LH}$ caused overall inhibition $(P<0.05)$ of progesterone production compared with treatment with each hormone alone. This interaction was not affected by the dose of $\mathrm{LH}$ used.

These findings indicate that $\mathrm{PGF}_{2 \alpha}$ and $\mathrm{PGE}_{2}$ are involved in the autocrine control of corpus luteum function.
\end{abstract}

Key'words: pig; luteal cells; prostaglandins; pregnancy

\section{Introduction}

The mechanisms regulating the function of the corpus luteum during early pregnancy in pigs are not fully understood, but it is generally accepted that uterine prostaglandins influence luteal lifespan in pigs (Anderson \& Melampy, 1967; Gleeson et al., 1974; Moeljono et al., 1976, 1977) and other species (Bazer et al., 1982). The pig corpus luteum seems to be refractory or insensitive to the luteolytic effect of exogenous prostaglandin $\mathrm{F}_{2 \alpha}\left(\mathrm{PGF}_{2 \alpha}\right)$ during the first 12 days of the oestrous cycle in vivo (Hallford et al., 1974; Guthrie \& Polge, 1976; Krzymowski et al., 1976, 1978; Bazer et al., 1982), presumably owing to the small number of luteal $\mathrm{PGF}_{2 a}$ receptors (Gadsby et al., 1990). An inhibitory effect of $\mathrm{PGF}_{2 \alpha}$, however, appears at about the time of luteolysis (day 11-13) in nonpregnant pigs (Guthrie \& Polge, 1976; Moeljono et al., 1976, 1977). During early pregnancy, days 13-17, endogenous uterine $\mathrm{PGF}_{2 a}$ secretion into the uterine vein is reduced (Gleeson et al., 1974; Moeljono et al., 1977), and luteal $\mathrm{PGF}_{2_{\alpha}}$ receptor concentrations are considerably lower than in nonpregnant pigs (Gadsby et al., 1990). However, the corpus luteum of cows

\footnotetext{
${ }^{*}$ Present address and address for correspondence: Dept of Animal Science, University of Alberta, Edmonton,
} Alberta, Canada T6G 2P5. 
(Shemesh \& Hansel, 1975; Milvae \& Hansel, 1983; Pate, 1988), ewes (Rexroad \& Guthrie, 1979), women (Challis et al., 1976), mares (Watson \& Sertich, 1990), monkeys (Johnson et al., 1988; Ottobre et al., 1989), rabbits (Schlegel et al., 1988; Schlegel \& Daniels, 1989) and cyclic (Patek \& Watson, 1976; Walker et al., 1977; Guthrie et al., 1978) or pregnant pigs (Watson \& Patek, 1979; Guthrie \& Rexroad, 1981) can synthesize prostaglandins.

Locally produced prostaglandins could play a role in regulating luteal function and may have an impact on luteal steroidogenesis (Fitz et al., 1984a, b; Hahlin et al., 1988; Pate \& Nephew, 1988; Alila et al., 1988; Wiltbank et al., 1989, 1990). PGF $_{2 \alpha}$ has a direct antisteroidogenic effect only on large ovine luteal cells, which is mediated through the phospholipase $\mathrm{C}$ - protein kinase $\mathrm{C}$, second messenger pathway (Wiltbank et al., 1989, 1990). Other prostaglandins, such as $E_{2}, I_{2}$ and $D_{2}$ are also produced by luteal tissue and prolong the lifespan of the corpus luteum in ewes (Huecksteadt \& Weems, 1978), cows (Milvae \& Hansel, 1983; Alila et al., 1988) and humans (Bennegard et al., 1990). Prostaglandin $\mathrm{E}_{2}\left(\mathrm{PGE}_{2}\right)$ also counteracts the effects of $P \mathrm{PF}_{2 \alpha}$ in indomethacin-treated cyclic gilts (Akinlosotu et al., 1986, 1988), but the mechanism of action of prostaglandins on luteal function in pigs is still unknown.

It is well established that the corpus luteum of the oestrous cycle of pigs does not require gonadotrophic support after the preovulatory surge of luteinizing hormone (LH) (Sammelwitz et al., 1961; Anderson \& Melampy, 1967) and treatment of gilts with LH antiserum during the luteal phase does not disrupt luteal function (Spies et al., 1967). The pig corpus luteum is not highly responsive to $\mathrm{LH}$ (Cook et al., 1967) in contrast to the corpus luteum of ruminants. However, it has been reported that $\mathrm{LH}$ may stimulate hydrolysis of phosphatidylinositol in isolated luteal membranes of pigs (Allen et al., 1988). Interaction between the two signal transducing systems cAMP and inositol may be important in the integrated control of luteal function.

The aim of this study was to elucidate the effects of $\mathrm{PGF}_{2 \alpha}$ and $\mathrm{PGE}_{2}$ on progesterone production by the corpus luteum at different stages of early pregnancy in pigs and to determine whether the interaction of $\mathrm{LH}$ with prostaglandins has an impact on steroidogenesis.

\section{Materials and Methods}

\section{Animals}

Sexually mature pigs (hybrid Landrace $\times$ Large White) were assigned randomly to four groups as follows: group 1. day 12 of the oestrous cycle; group 2, day 12, group 3, day 20 and group 4, day 30 of pregnancy. Oestrus was checked daily using a vasectomized boar and the day of mating to fertile boars and the first day of behavioural oestrus was designated day 0 in pregnant and cyclic gilts, respectively. Pregnancy was confirmed by recovery of spherical, filamentous or expanded embryos after dissection of the uterus.

\section{Cell preparation and incubation}

Ovaries were removed immediately after slaughter, placed in ice-cold Eagle's minimum essential medium MEM (Flow Laboratories, UK) and transported to the laboratory. Corpora lutea were dissected from the ovaries and the surrounding tissue was removed. Luteal cells were dispersed with $0.1 \%$ collagenase (Sigma, Poole, UK) and gentle mechanical agitation of the luteal tissue. Luteal cell viability, as determined by trypan blue $(0.2 \%)$ exclusion, was $75-$ $80 \%$. Suspensions of dispersed luteal cells were incubated in a shaking water bath at $5 \times 10^{4}$ cells in $1 \mathrm{ml}$ Eagle's minimum essential medium (MEM) at $39^{\circ} \mathrm{C}$ for $2 \mathrm{~h}$ without and with different doses of hormones (experimental treatments). At the end of incubation, cells were sedimented by centrifugation at $1000 \mathrm{~g}$ for $10 \mathrm{~min}$ and medium was stored at $-20^{\circ} \mathrm{C}$ until estimation of net progesterone accumulation by radioimmunoassay (Foxcroft et al., 1987). The intra- and interassay coefficients of variation were 5.3 and $15.8 \%$, respectively; assay sensitivity was 20 pg per tube.

\section{Experimental treatments}

Treatments across all groups were prostaglandins $F_{2 \alpha}$ or $E_{2}$ (both from Sigma) at $0,0 \cdot 01,0 \cdot 1,1,10,100$ and $1000 \mathrm{ng} \mathrm{ml}^{-1}$, porcine LH (NIH-pLH, Bethesda, USA) at 100 or $1000 \mathrm{ng} \mathrm{ml}^{-1}$ and combinations of PGF PG $_{2 u}$ and 
or $\mathrm{PGE}_{2}$ and $\mathrm{LH}$. Additionally, $\mathrm{PGF}_{2 a}$ and $\mathrm{PGE}_{2}$ each at equal concentrations of 10,100 and $1000 \mathrm{ng} \mathrm{ml}^{-1}$ were added to incubation tubes. Experimental treatments were performed in duplicate for each pig.

\section{Statistical analysis}

The experiment was analysed using split-plot analysis of variance (Steel \& Torrie, 1980). Whole plots were the groups $(G=4)$ with five animals per group. The split plots were the combinations of prostaglandins (either $F_{2 u}$ or $E_{2}$; $\mathrm{P}=7)$ and $\mathrm{LH}(\mathrm{L}=3)$. Specific contrasts among the means were computed as shown in Table 1 . Within each of the three concentrations of prostaglandins $\left(10.100\right.$ and $1000 \mathrm{ng} \mathrm{ml}^{-1}$ ), the data for PGF $_{2 a}$ plus PGE $_{2}$ were combined with the control $(0)$ and the appropriate prostaglandins $E_{2}$ or $F_{2 u}$. The data were analysed as a split plot with groups $(G=4)$ as the whole plots and five animals per group. The split plot contained one concentration of each prostaglandin and co-treatment.

Table 1. Summary of specific contrasts made in the analysis of variance for the split-plot design

\begin{tabular}{|c|c|}
\hline ANOVA source & Contrast \\
\hline LH & $\begin{array}{l}\mathrm{LH} 0 \text { versus ( } \mathrm{LH} 100 \mathrm{ng} \mathrm{ml}^{-1}+\mathrm{LH} \\
\left.\mathrm{l} 000 \mathrm{ng} \mathrm{ml}^{-1}\right)\end{array}$ \\
\hline Group*LH & $\begin{array}{l}\text { [(group } 1+\text { group } 2) \text { versus (group } 3+ \\
\text { group 4) }]^{*}[\text { LH } 0 \text { versus }(\mathrm{LH} 100 \mathrm{ng} \\
\left.\left.\mathrm{ml}^{-1}+\mathrm{LH} 1000 \mathrm{ng} \mathrm{ml}^{-1}\right)\right]\end{array}$ \\
\hline $\mathrm{PGF}_{2 a}$ & $\mathrm{PGF}_{2 \alpha}$ (linear) \\
\hline Group $^{*} \mathrm{PGF}_{2 a}$ & $\begin{array}{l}\text { (group } 1 \text { versus group 2)*PGF } \text { Pa }_{a} \text { (group } \\
1+\text { group 2) versus (group } 3+\text { group } \\
4 \text { ) }]^{*} \mathrm{PGF}_{2 u}\end{array}$ \\
\hline $\mathrm{LH}^{*} \mathrm{PGF}_{2 a}$ & $\begin{array}{l}{\left[\mathrm{LH} 0 \text { versus }\left(\mathrm{LH} 100 \mathrm{ng} \mathrm{ml}^{-1}+\mathrm{LH}\right.\right.} \\
\left.\left.1000 \mathrm{ng} \mathrm{ml}^{-1}\right)\right]^{* \mathrm{PGF}_{2 u}}\end{array}$ \\
\hline $\mathrm{PGE}_{2}$ & $\mathrm{PGE}_{2}$ (quadratic) \\
\hline Group*PGE 2 & $\begin{array}{l}\text { [(group } 1+\text { group 2) versus (group } 3+ \\
\text { group 4)]*PGE }\end{array}$ \\
\hline $\mathrm{LH}^{*} \mathrm{PGE}_{2}$ & $\begin{array}{l}{\left[\mathrm{LH} 0 \text { versus }\left(\mathrm{LH} 100 \mathrm{ng} \mathrm{ml}^{-1}+\mathrm{LH}\right.\right.} \\
\left.\left.1000 \mathrm{ng} \mathrm{ml}^{-1}\right)\right]^{*} \mathrm{PGE}_{2}\end{array}$ \\
\hline
\end{tabular}

LH: luteinizing hormone; $\mathrm{PGF}_{2 a}$ : prostaglandin $\mathrm{F}_{2 \alpha}$; $\mathrm{PGE}_{2}$ : prostaglandin $\mathrm{E}_{2}$; LH 0 : without LH treatment (control).

\section{Results}

The initial analysis of variance revealed group $(P<0.05)$ and $\mathrm{LH}, \mathrm{PGE}_{2}$ and $\mathrm{PGF}_{2 \alpha}$ effects $(P<0.0001)$ and significant interactions (at least $P<0.02)$. Specific contrasts in the split-plot analysis (see Table 1) demonstrated that treatment of luteal cells with increasing doses of $\mathrm{PGF}_{2 \alpha}$ (Fig. 1) produced an overall linear increase $(P<0.05)$ in progesterone production, whereas $\mathrm{PGE}_{2}$ treatment (Fig. 2) produced an overall quadratic response $(P<0.05)$ described by the equation $y=12.20+0.026 \times \mathrm{PGE}_{2}-0.000024 \times\left(\mathrm{PGE}_{2}\right)^{2}\left(r^{2}=0.27\right)$. The overall LH effect $(P<0.05)$ was independent of the dose used except on day 12 of pregnancy when there was a significant $(P<0.05)$ dose-dependent increase in progesterone production in response to $\mathrm{LH}$ treatment. There were no differences in the pattern of response of luteal cells between the cyclic and pregnant pigs on day 12 or days 20 and 30 of pregnancy; in subsequent analyses data from appropriate groups were therefore combined. Progesterone secretion on day 12 of the oestrous cycle and pregnancy was significantly higher $(P<0.05)$ and more responsive to exogenous $\mathrm{LH}, \mathrm{PGF}_{2 \alpha}$ and $\mathrm{PGE}_{2}$ treatment $(P<0.05)$ than on days 20 and 30 of pregnancy. Treatment of luteal cells with PGF $_{2 \alpha}$ plus $\mathrm{LH}$ or $\mathrm{PGE}_{2}$ plus $\mathrm{LH}$ produced overall $(P<0.05)$ inhibition of progesterone production compared with incubations with $\mathbf{L H}$ or with prostaglandin alone. The doses of $\mathrm{LH}$ used did not influence the overall response to these combined treatments. 


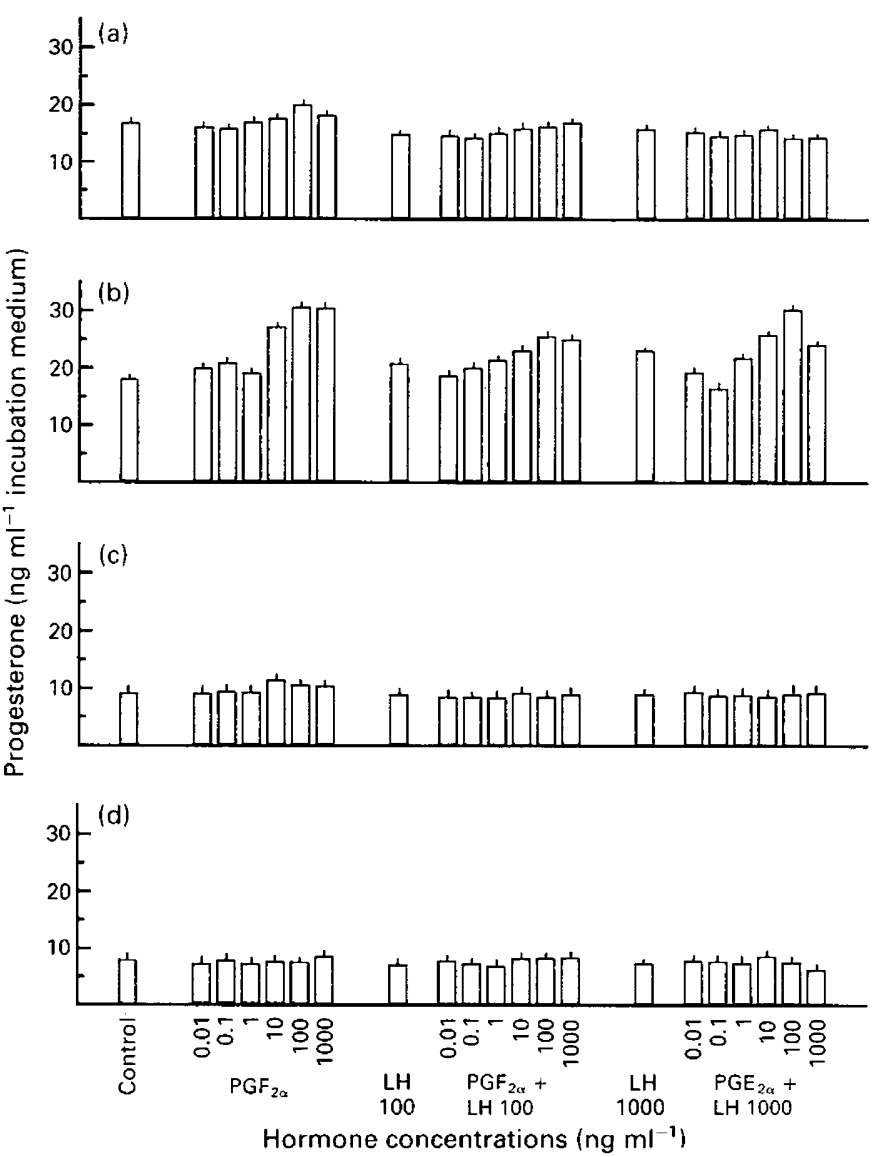

Fig. 1. Effect of prostaglandin $\mathrm{F}_{2 \alpha}\left(\mathrm{PGF}_{2 \alpha}\right)$, luteinizing hormone (LH) and $\mathrm{PGF}_{2 \alpha}$ plus $\mathrm{LH}$ on progesterone production for $2 \mathrm{~h}$ incubation by luteal cells dissociated from the corpora lutea of (a) day 12 cyclic and days 12 (b), 20 (c) and 30 (d) pregnant pigs. Each bar represents the mean derived from duplicate observations from five gilts; SEM for whole plot $=1 \cdot 48$; vertical bars indicate SEM.

The results provide preliminary evidence for an interaction between equal concentrations of $\mathrm{PGF}_{2 \alpha}$ and $\mathrm{PGE}_{2}$ affecting progesterone production by luteal cells (Fig. 3). When data for all groups were combined, there were significant interactions $(P<0.0001)$ between $\mathrm{PGF}_{2 a}$ and $\mathrm{PGE}_{2}$ at doses of 10,100 and $1000 \mathrm{ng} \mathrm{ml}^{-1}$ incubation medium except on day 30 of pregnancy.

\section{Discussion}

This study showed that $\mathrm{PGF}_{2 \alpha}$ stimulates progesterone production in vitro by luteal cells of midluteal phase and early pregnant pigs. We suggest that this stimulatory effect could be mediated through the low-affinity receptors present on small luteal cells (Gadsby et al., 1990), as the small luteal cells are known to be the predominant cell type in our suspension (data not shown). Mattioli et al. (1985) have shown that in short-term incubations, $\mathrm{PGF}_{2 a}$ stimulated progesterone production by dispersed luteal cells (mid-luteal phase) of pigs in a dose-dependent manner. Similarly, PGF $_{2 \alpha}$ stimulated progesterone secretion in bovine small luteal cells in vitro, presumably acting through the phospholipase-C-phosphatidylinositol hydrolysis and mobilization of intracellular $\mathrm{Ca}^{2+}$ 

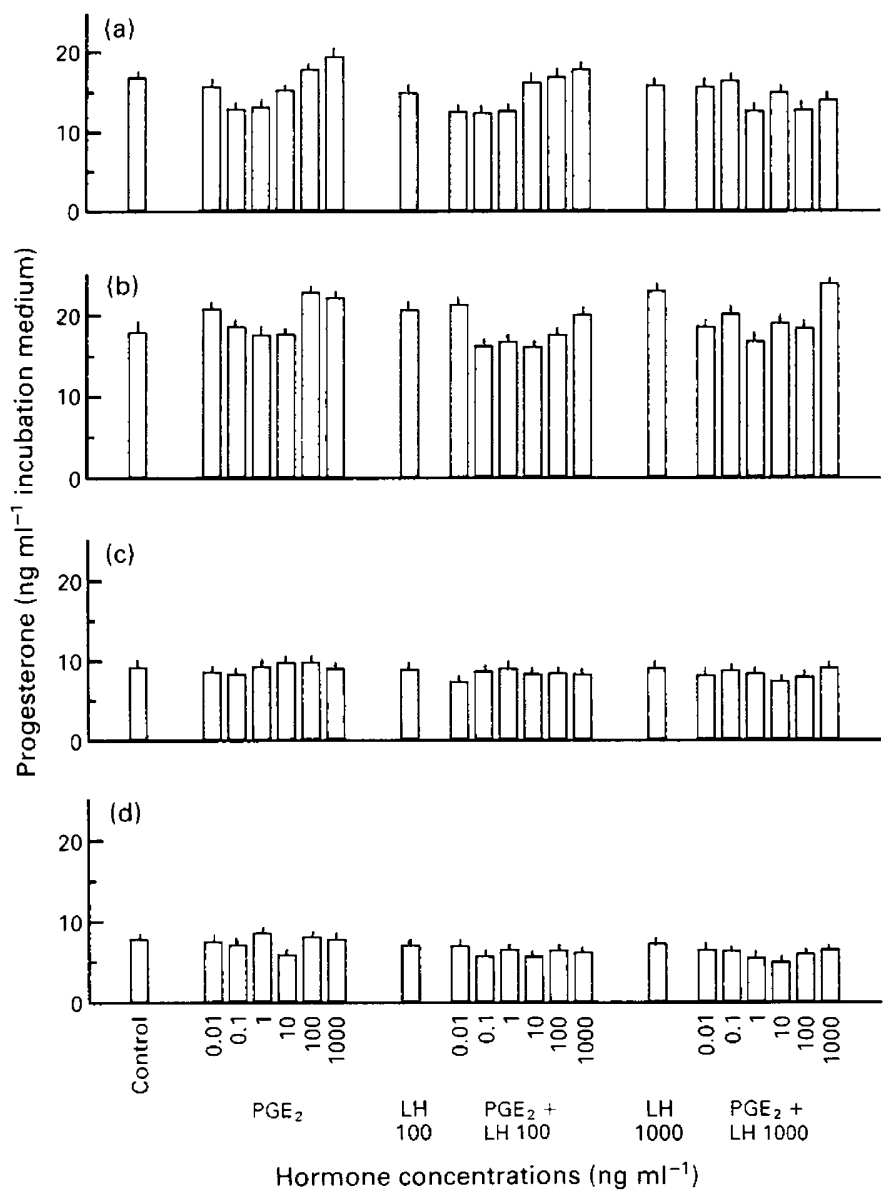

Fig. 2. Effect of prostaglandin $E_{2}$, luteinizing hormone (L.H) and $\mathrm{PGE}_{2}$ plus $\mathrm{LH}$ on progesterone production for $2 \mathrm{~h}$ incubation by luteal cells dissociated from the corpora lutea of (a) day 12 cyclic and days 12 (b), 20 (c) and 30 (d) pregnant pigs. Each bar represents the mean derived from duplicate observations from gilts; SEM for whole plot $=1.47$; vertical bars indicate SEM.

(Davis et al., 1987, 1989). Prostaglandin $\mathrm{F}_{2 \alpha}$ inhibits luteal steroidogenesis in vitro when lipoproteins are present in the culture medium (Pate \& Nephew, 1988; Wiltbank et al., 1990) and incubation times were longer than 4-6 h (Fritz et al., 1991). The cells in our study were incubated in MEM without any supplementation (bovine serum albumin or serum) to avoid interactions between blood proteins and $\mathrm{PGE}_{2}$; this may explain why we could not inhibit progesterone production in vitro by $\mathrm{PGF}_{2 \alpha}$ treatment of luteal cells. Furthermore, the lack of a luteolytic effect of $\mathrm{PGF}_{2 \alpha}$ could be due to the presence of only a small number of large luteal cells (the target for the luteolytic effects of $\mathrm{PGF}_{2 \alpha}$ ) in our incubation samples or because the incubation time was too short to permit luteolytic effects of $\mathrm{PGF}_{2 \alpha}$ to occur. It has been suggested that the cytotoxic effect of $\mathrm{PGF}_{2 \alpha}$ on small luteal cells is mediated through indirect mechanisms, such as intercellular communication from large cells (Braden et al., 1988); the disruption of these intercellular communications may therefore have had an effect. Data reported here are consistent with the recent demonstration that injection of a luteolytic dose of $\mathrm{PGF}_{2 a}$ to both pregnant and pseudopregnant gilts produced a rapid and transient increase in serum progesterone concentrations lasting approximately $1 \mathrm{~h}$ (Gadsby et al., 1991). $\mathrm{PGF}_{2 a}$ may stimulate progesterone synthesis or secretion in porcine luteal cells in vivo before the subsequent decline in serum concentrations of progesterone associated with luteolysis in most pregnant animals. Gadsby et al. (1991) suggest that there may be a causal relationship 


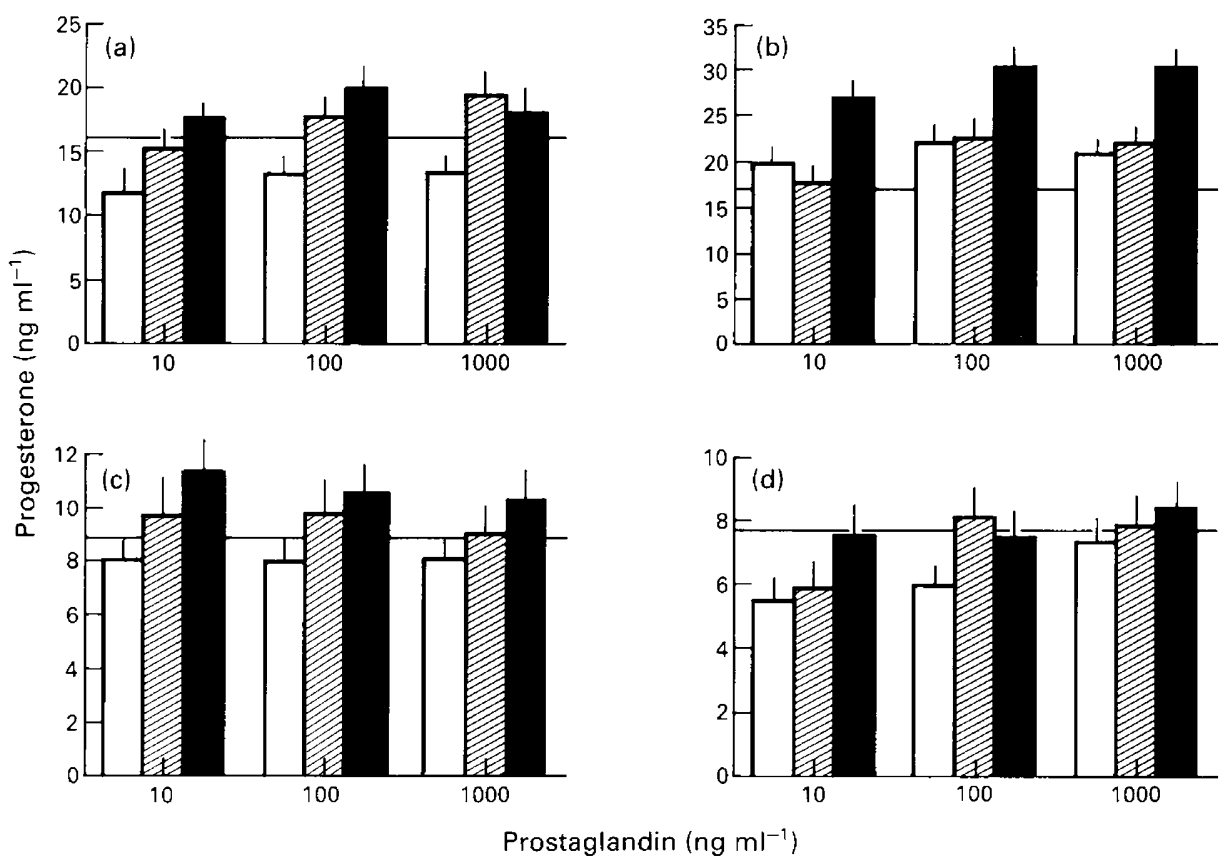

Fig. 3. Effect of prostaglandins $F_{2 u}(\square)$ and $E_{2}(\ell d)$ alone or combined in equal doses $(\square)$ on progesterone production in vitro by luteal cells recovered from the groups of (a) day 12 cyclic and days 12 (b), 20 (c) and 30 (d) pregnant gilts. The horizontal line represents the progesterone production by luteal cells without any treatment. Overall SEM for prostaglandins doses: 1.58 for $10 \mathrm{ng} \mathrm{ml}^{-1}, 1.46$ for $100 \mathrm{ng} \mathrm{ml}^{-1}, 1.69$ for $1000 \mathrm{ng} \mathrm{ml}^{-1}$; vertical bars indicate SEM.

between the early stimulatory and the later inhibitory (luteolytic) actions of $\mathrm{PGF}_{2 \alpha}$ on porcine luteal cells. Similarly, Watson \& Maule-Walker (1977) used superfused porcine luteal tissue slices to show that a transient stimulation in progesterone output preceded the inhibitory effect of PGF $2 u$ on progesterone production.

The pattern of response of luteal cells to exogenous hormones on day 12 of the oestrous cycle and pregnancy was different to that on days 20 and 30 of pregnancy. The progesterone deficiency (low basal progesterone production and reduced responsiveness to prostaglandins, LH or LH plus prostaglandins treatment) in the early pregnancy of pigs (day 20 and 30) may have been caused by the initiation of luteolysis on day 11 (Bazer et al., 1982) by prostaglandins of luteal origin, as suggested by Rothchild (1981). Guthrie \& Rexroad (1981) demonstrated that the peak of PGF $2 a$ secretion during the late luteal phase in nonpregnant pigs usually occurs after the initial decrease in plasma progesterone. The results from studies in vivo (Bazer et al., 1982) showed that peripheral progesterone in the blood decreased to $10-25 \mathrm{ng} \mathrm{ml}^{-1}$ on days $20-30$ of pregnancy, whereas prostaglandin concentrations in the utero-ovarian vein were very low and similar to those in hysterectomized pigs (King, 1990). The extent of the initiation of a transient period of luteolysis in early pregnancy would not be expected to mimic fully the changes seen during the oestrous cycle due to: (i) the considerably smaller number of $\mathrm{PGF}_{2 a}$ receptors on the corpus luteum of pregnant compared with nonpregnant pigs (Gadsby et al., 1990), (ii) the lack of luteolytic factors from the uterus, as it is well documented that during pregnancy uterine $\mathrm{PGF}_{2 \alpha}$ is sequestered in the uterus (Bazer et al., 1982) and (iii) it is likely that the corpus luteum would already have received luteotrophic support of embryonic (Dhindsa \& Dziuk, 1968; Ball \& Day, 1979; Van der Meulen et al., 1988) or pituitary (Brinkley et al., 1964, authors' unpublished observations) origin.

Unfortunately, we do not know the origin of prostaglandins within the pig corpus luteum in vivo or within luteal cell suspensions in vitro, or what regulates the synthesis and balance of these 
arachidonate metabolites. These issues are currently under investigation. If we assume that the luteal production of prostaglandins could be the physiological signal triggering a transient luteolysis in early pregnancy, then the corpus luteum has to be rescued for pregnancy to continue in pigs. It has been suggested (Hahlin et al., 1988; Bennegard et al., 1990) that the hormone that rescues or protects the corpus luteum from the luteolytic effects of $\mathrm{PGF}_{2 \alpha}$ during early pregnancy is $\mathrm{PGE}_{2}$ in humans (Balmaceda et al., 1981). The role of $\mathrm{PGE}_{2}$ in corpus luteum function during early pregnancy of pigs is unknown. However, $\mathrm{PGE}_{2}$ can counteract the luteolytic effect of $\mathrm{PGF}_{2 a}$, since chronic intrauterine infusions of $\mathrm{PGE}_{2}$ from day 7 in cyclic gilts (Akinlosotu et al., 1986, 1988), and day 9 in cows (Gimenez \& Henricks, 1981) and ewes (Pratt et al., 1979), inhibits luteolysis, maintains luteal progesterone production and prolongs the oestrous cycle. Shelton et al. (1990) have indicated that $\mathrm{PGE}_{2}$ can stimulate progesterone synthesis and may also have inhibitory effects on bovine luteal cells during early pregnancy. Our results are generally in agreement with these observations, with the exception that the porcine luteal cells did not respond to $\mathrm{PGE}_{2}$ treatment in a simple dose dependent manner. Large, as well as pools of small and large, ovine luteal cells (Fitz et al., 1984b; Balapure et al., 1989) also exhibited a quadratic pattern of response to $\mathrm{PGE}_{2}$ but in a reverse manner to pig luteal cells, with maximum stimulation resulting from media concentrations of $\mathrm{PGE}_{2}$ between 10 and $50 \mathrm{ng} \mathrm{ml}^{-1}$. The physiological basis for these different dose-dependent quadratic effects may be related to a number of factors: (i) the different developmental status of the target tissues due to differences between the species or culture conditions; (ii) the functional status of $\mathrm{PGE}_{2}$ and $\mathrm{PGF}_{2 \alpha}$ receptors on luteal cells which can regulate crossreactivities of different prostaglandins with their receptors and (iii) the relative proportions of $\mathrm{PGE}_{2}$ to $\mathrm{PGF}_{2 a}$ in the corpus luteum in different physiological states.

Our studies also demonstrated that $\mathrm{LH}$ and prostaglandins $\mathrm{F}_{2 \alpha}$ and $\mathrm{E}_{2}$ interact to inhibit progesterone production by pig luteal cells. Shelton et al. (1990) showed that low concentrations of $\mathrm{PGE}_{2}\left(0 \cdot 01-10 \mathrm{ng} \mathrm{ml}^{-1}\right)$ inhibit progesterone production stimulated by lower doses of $\mathrm{LH}(0 \cdot 1 \mathrm{ng}$ $\mathrm{ml}^{-1}$ ), but this was overcome by higher concentrations of $\mathrm{PGE}_{2}\left(>100 \mathrm{ng} \mathrm{m}^{-1}\right)$. In addition higher doses of LH did not inhibit the effect of low doses of $\mathrm{PGE}_{2}$ upon progesterone synthesis. Nevertheless, $\mathrm{PGE}_{2}$ was as efficient as $\mathrm{PGF}_{2 a}$ in inhibiting $\mathrm{LH}$ stimulated progesterone synthesis in dispersed rat luteal cells (Thomas et al., 1978). A similar antagonistic effect of $\mathrm{PGE}_{2}$ on human chorionic gonadotrophin stimulation of luteal cells from rhesus monkeys has been reported (Stouffer et al., 1979). Finally, $\mathrm{LH}$ and $\mathrm{PGF}_{2 u}$ interact in large luteal cells of cows to produce $\mathrm{Ca}^{2+}$ concentrations that are higher than the sum of $\mathrm{Ca}^{2+}$ produced by each hormone separately (Alila et al., 1989). Results reported here and in other studies indicate that the interaction of the two intracellular second messenger pathways ( $\mathrm{LH}$ and prostaglandins) has a negative effect on progesterone production by luteal cells. This conclusion is further supported by the work of Davis et al. $(1987,1989)$ who showed that LH can activate the inositol phospholipid-phospholipase C signalling system in bovine luteal cells.

It is generally recognized that $\mathrm{LH}$ is a luteotrophic hormone in many species and its effect is mediated through an intracellular cAMP mechanism, but the luteotrophic influence of LH on the pig corpus luteum is still uncertain. Ekstrom \& Hunzicker-Dunn (1990) demonstrated that pig luteal membranes were resistant to in vitro, hormone-induced, desensitization of $\mathrm{LH} / \mathrm{hCG}$ responsive adenylyl cyclase when compared with follicular membranes; hormonal stimulation was readily observed by extracting the membranes with urea, and GTP was required during the assay. They also suggested that some auxiliary factor in the corpus luteum could be responsible for the resistance of pig luteal adenylyl cyclase to desensitization.

In this study, the effect of LH alone on progesterone production was not consistent across the groups and was dose dependent only on day 12 of pregnancy. This supports the suggestion of Ekstrom \& Hunzicker-Dunn (1990) that the activity of LH receptors, or changes in the classes of LH/ hCG receptors, may be of critical importance in regulating the response to gonadotrophic stimulation. It is also in agreement with our unpublished observation that incubation conditions and the physiological state of the ovary (i.e. day of pregnancy) play important roles in responsiveness to LH. 
We conclude that prostaglandins exert both stimulatory and inhibitory effects on the activity of porcine luteal cells. They can also interact with $\mathrm{LH}$ and with each other, indicating multiple sites of action. We therefore suggest that the ratios of $\mathrm{LH}$, prostaglandins $\mathrm{E}_{2}$ and $\mathrm{F}_{2 \alpha}$ are important in the control of progesterone synthesis during early pregnancy in pigs.

We thank S. Woodward for technical assistance, R. T. Hardin and G. Godby for assistance with statistical analysis of our data, E. Beltranena for help in preparing figures and S. Lynch for the provision of antisera. This study received financial support from the AFRC and JRF (postdoctoral fellowship to T. Wiesak); during the later analytical stage of the study G. R. Foxcroft and T. Wiesak were recipients of financial support from the Natural Sciences and Engineering Research Council of Canada and from the Alberta Pork Producers' Development Corporation.

\section{References}

Akinlosotu, B.A., Diehl, J.R. \& Gimenez, T. (1986) Sparing effects of intrauterine treatment with prostaglandins $E_{2}$ on luteal function in cyclic gilts. Prostaglandins 32, 291-299.

Akinlosotu, B.A., Diehl, J.R. \& Gimenez, T. (1988) Prostaglandins $\mathrm{E}_{2}$ counteracts the effects of $\mathrm{PGF}_{2 u}$ in indomethacin treated cyclic gilts. Prostaglandins 35, 81-93.

Alila, H.W., Corradino, R.A. \& Hansel, W. (1988) A comparison of the effects of cyclooxygenase prostanoids of progesterone production by small and large bovine luteal cells. Prostaglandins 36, 259-270.

Alila, H.W., Corradino, R.A. \& Hansel, W. (1989) Differential effects of luteinizing hormone on intracellular free $\mathrm{Ca}^{2+}$ in small and large bovine luteal cells. Endocrinology 124, 2314-2320.

Allen, R.B., Su, H.C., Snitzer, J. \& Dimino, M.J. (1988) Rapid decreases in phosphatidylinositol in isolated luteal plasma membranes after stimulation by luteinizing hormone. Biology of Reproduction 38, 79-83.

Anderson, L.L. \& Melampy, R.M. (1967) Hypophysial and uterine influence on pig luteal function. In Reproduction in the Female Mammals, pp. 285-316. Ed. G. E. Lamming \& E. C. Amoroso. Butterworths, London.

Balapure, A.K., Caicedo, I.C., Kawada, K., Watt, D.S., Rexroad, C.E., Jr \& Fitz, T.A. (1989) Multiple classes of $\mathrm{PGF}_{2 \alpha}$ binding sites in subpopulations of ovine luteal cells. Biology of Reproduction 41, 385-392.

Ball, G.D. \& Day, B.N. (1979) Effects of embryonic extracts on luteal function in the pig. Journal of Animal Science 49 (Supplement 1), Abstract 279.

Balmaceda, J., Valenzuela, G., Eddy, C. \& Asch, R. (1981) Effects of hCG on prostaglandin synthesis and function of corpus luteum. Journal of Obstetrics and Gynaecology 57, 505 508.

Bazer, F.W., Geisert, R.D., Thatcher, W.W. \& Roberts, R.M. (1982) The establishment and maintenance of pregnancy. In Control of Pig Reproduction, pp.227-253. Ed. D. J. A. Cole \& G. R. Foxcroft. Butterworths, London.

Bennegard, B., Hahlin, M. \& Hamberger, L. (1990) Luteotropic effects of prostaglandins $I_{2}$ and $D_{2}$ on isolated human corpora lutea. Fertility and Sterility 54, $459-464$.

Braden, T.D., Gamboni, F. \& Niswender, G.D. (1988) Effects of prostaglandin $F_{2 u}$ induced luteolysis on the populations of cells in the ovine corpus luteum. Biology of Reproduction 39, 245-253.

Brinkley, H.J., Norton, H.W. \& Nalbandov, A.V. (1964) Role of a hypophysial luteotrophic substance in the function of porcine corpora lutea. Endocrinology 74, 9-13.

Challis, J.R.G., Calder, A.A., Dilley, S., Forster, C.S., Hillier, K., Hunter, D.J.S., MacKenzie, I.Z. \& Thorburn, G.D. (1976) Production of prostaglandins $E$ and $F_{2 a}$ by corpora lutea, corpora albicantes and stroma from the human ovary. Journal of Endocrinology 68, 401-408.

Cook, B., Kaltenbach, C.C., Norton, H.W. \& Nalbandov, A.V. (1967) Synthesis of progesterone in vitro by porcine corpora lutea. Endocrinology 81, 573-581.

Davis, J.S., Weakland, L.L., Farese, R.V. \& West, L.A. (1987) Luteinizing hormone increases inositol trisphosphate and cytosolic free $\mathrm{Ca}^{2+}$ in isolated bovine luteal cells. Journal of Biological Chemistry 262, 8515-8521.

Davis, J.S., Alila, H.W., West, L.A., Corradino, R.A., Weakland, L.L. \& Hansel, W. (1989) Second messenger systems and progesterone secretion in the small cells of the bovine corpus luteum: effects of gonadotropins and prostaglandins $F_{2 a}$. Journal of Steroid Biochemistry 32, 643-649.

Dhindsa, D.S. \& Dziuk, P.J. (1968) Effects of pregnancy in the pig after killing embryos or fetuses in one uterine horn in early pregnancy. Journal of Animal Science 27, 122-126.

Ekstrom, R. \& Hunzicker-Dunn, M. (1990) Comparison of the luteinizing hormone-sensitive adenylyl cyclase of the pig ovarian follicle and corpus luteum and its susceptibility to in vitro hormone-dependent desensitization. Endocrinology 126, 1191-1198.

Fitz, T.A., Hoyer, P.B. \& Niswender, G.D. (1984a) Interaction of prostaglandins with sub-populations of ovine luteal cells. I. Stimulatory effects of prostaglandins E-1, E-2 and I-2. Prostaglandins 28, 119-126.

Fitz, T.A., Mock, E.J., Mayan, M.H. \& Niswender, G.D. (1984b) Interactions of prostaglandins with subpopulations of ovine luteal cells. II. Inhibitory effects of $\mathbf{P G F}_{2 a}$ and protection by $\mathrm{PGE}_{2}$. Prostaglandins 28, $127-138$. 
Foxcroft, G.R., Shaw, H.J., Hunter, M.G., Booth, P.J. \& Lancaster, R.T. (1987) Relationship between luteinizing hormone, follicle-stimulating hormone and prolactin secretion and ovarian follicular development in the weaned sow. Biology of Reproduction 36, 175-191.

Fritz, M.A., Marr, M.M., Rexroad, C.E., Jr \& Fitz, T.A. (1991) Prostaglandin interactions in ovine luteal cells maintained in long term culture by steroidogenic substrate supplementation with lipoprotein or a cholesterol analog. Biology of Reproduction 40, Supplement 1, pp. 111 , Abstract 234.

Gadsby, J.E., Balapure, A.K., Britt, J.H. \& Fitz, T.A. (1990) Prostaglandins $F_{2 a}$ receptors on enzymedissociated pig luteal cells throughout the estrous cycle. Endocrinology 126, 787-795.

Gadsby, J.E., Smith, C.A. \& Almond, G.W. (1991) Acute stimulatory effects of prostaglandin $F_{2 a}$ on serum progesterone concentrations in pregnant and pseudopregnant pigs. Prostaglandins 41, 419-432.

Gimenez, T. \& Henricks, D.M. (1981) Prolongation of the luteal phase by prostaglandin $E_{2}$ during the estrous cycle in the cow. Theriogenology 19,693-698.

Gleeson, A.R., Thorburn, G.D. \& Cox, R.I. (1974) Prostaglandins F concentrations in the utero-ovarian vein plasma of the sow during the late luteal phase of the estrous cycle. Prostaglandins 5, 521-530.

Guthrie, H.D. \& Polge, C. (1976) Luteal function and oestrus in gilts treated with a synthetic analogue of prostaglandins $\mathrm{F}_{2 a}$ (ICI 79,939) at various times during the oestrous cycle. Journal of Reproduction and Fertility 48, 423-425.

Guthrie, H.D. \& Rexroad, C.E., Jr (1981) Endometrial prostaglandin $F$ release in vitro and plasma 13,14dihydro-15-keto-prostaglandin $\mathrm{F}_{2 a}$ in pigs with luteolysis blocked by pregnancy, estradiol benzoate or human chorionic gonadotropin. Journal of Animal Science 52, 330-339.

Guthrie, H.D., Rexroad, C.E., Jr \& Bolt, D.J. (1978) In vitro synthesis of progesterone and prostaglandins $F$ by luteal tissue and prostaglandins $F$ by endometrial tissue from the pig. Prostaglandins 16, 433-440.

Hahlin, M., Dennefors, B., Johanson, C. \& Hamberger, L. (1988) Luteotropic effects of prostaglandin $E_{2}$ on the human corpus luteum of the menstrual cycle and early pregnancy. Journal of Clinical Endocrinology and Metabolism 66, 909-914.

Hallford, D.M., Wettemann, R.P., Turnman, E.J. \& Omtvedt, I.T. (1974) Luteal function in gilts after prostaglandins $\mathrm{F}_{2 \alpha}$. Journal of Animal Science 28, Abstract 213.

Huecksteadt, T. \& Weems, C. (1978) Effect of PGE 1 on normal luteolysis and $\mathrm{PGE}_{1}$ or $\mathrm{PGE}_{2}$ on IUDinduced luteolysis in ewes. The Pharmacologist 20, 233, Abstract 441 .

Johnson, M.S., Ottobre, A.C. \& Ottobre, J.S. (1988) Prostaglandin production by corpora lutea of Rhesus monkeys: characterization of incubation conditions and examination of putative regulators. Biology of Reproduction 39, 839-846.

King, G.J. (1990) Maternal recognition of pregnancy precedes prevention of luteolysis in pigs. 12th Annual Winter Workshop: In vitro Fertilization and Early Embryonic Culture. p. 38, Abstract 26.
Krzymowski, T., Kotwica, J., Okrasa, S. \& Doboszynska, T. (1976) The function and regression of corpora lutea during the sow's estrous cycle after 10 hours of prostaglandins $\mathrm{F}_{2 a}$ infusion into the anterior uterine vein. Proceedings VIII International Congress Animal Reproduction, Krakow, p. 143.

Krzymowski, T., Kotwica, J., Okrasa, S., Doboszynska, T. \& Ziecik, A. (1978) Luteal function in sows after unilateral infusion of $\mathrm{PGF}_{2 a}$ into the anterior uterine vein on different days of the oestrous cycle. Journal of Reproduction and Fertility 54, 21-27.

Mattioli, M., Galeati, G., Prandi, A. \& Seren, E. (1985) Effect of $\mathrm{PGF}_{2 u}$ on progesterone production in swine luteal cells at different stages of the luteal phase. Prostaglandins Leukotrienes and Medicine 17, 43-54.

Milvae, R.A. \& Hansel, W. (1983) Prostacyclin, prostaglandins $\mathrm{F}_{2 a}$ and progesterone production by bovine luteal cells during the estrous cycle. Biology of Reproduction 29, 1063-1068.

Moeljono, M.P.E., Bazer, R.W. \& Thatcher, W.W. (1976) A study of prostaglandin $F_{2 a}$ as the luteolysin in swine: 1. Effect of prostaglandins $F_{2 u}$ in hysterectomized gilts. Prostaglandins 11, 737 743 .

Moeljono, M.P.E., Thatcher, W.W., Bazer, F.W., Frank, M., Owens, L.J. \& Wilcox, C.J. (1977) A study of prostaglandins $F_{2 a}$ as the luteolysin in swine: II. Characterization and comparison of prostaglandins $F$, estrogen and progestin concentrations in utero-ovarian vein plasma of nonpregnant gilts. Prostaglandins 14, 543-555.

Ottobre, J.S., Houmard, B.S. \& Ottobre, A.C. (1989) Luteal production of steroids and prostaglandins during simulated early pregnancy in the primate: differential regulation of steroid production by chorionic gonadotropin. Biology' of Reproduction 41, 393. 400 .

Pate, J.L. (1988) Regulation of prostaglandin synthesis by progesterone in the bovine corpus luteum. Prostaglandins 36, 303-315.

Pate, J.L. \& Nephew, K.P. (1988) Effects of in vivo and in vitro administration of prostaglandins $\mathrm{F}_{2 \alpha}$ on lipoprotein utilization in cultured bovine luteal cells. Biology of Reproduction 38, 568-576.

Patek, C.E. \& Watson, J. (1976) Prostaglandin F and progesterone secretion by porcine endometrium and corpus luteum in vitro. Prostaglandins 12, 97-111.

Pratt, B.R., Butcher, R.L. \& Inskeep, E.K. (1979) Effect of continuous intrauterine administration of prostaglandins $\mathrm{E}_{2}$ on lifespan of corpora lutea of nonpregnant ewes. Journal of Animal Science 48, 1441-1446.

Rexroad, C.F., Jr \& Guthrie, H.D. (1979) Prostaglandins $\mathrm{F}_{2 u}$ and progesterone release in vitro by ovine luteal tissue during induced luteolysis. In Ovarian Follicular and Corpus Luteum Function, pp. 639-644. Eds C. P. Channing, J. M. Marsh \& W. A. Sadler. Plenum Press, New York.

Rothchild, J. (1981) The regulation of the mammalian corpus luteum. Recent Progress in Hormone Research 47, $183-298$.

Sammelwitz, P.H., Aldred, J.P. \& Nalbanov, A.V. (1961) Mechanisms of maintenance of corpora lutea in pigs and rats. Journal of Reproduction and Fertility 2, 387-393. 
Schlegel, W. \& Daniels, D. (1989) Studies on the prostaglandins E-2-9 ketoreductase mediated production of prostaglandin F-2 $\alpha$ and its metabolism in cultured rabbit luteal cells. Acta Endocrinologica 121, 395-400.

Schlegel, W., Kruger, S., Daniels, D., Fischer, B., Schneider, H.P.G. \& Beier, H.M. (1988) Studies on prostaglandin metabolism in corpora lutea of rabbits during pregnancy and pseudopregnancy. Journal of Reproduction and Fertility 83, 365-370.

Shelton, K., Parkinson, T.J., Hunter, M.G., Kelly, R.W. \& Lamming, G.E. (1990) Prostaglandin E-2 as a potential luteotrophic agent during early pregnancy in cattle. Journal of Reproduction and Fertility 90, 11.17.

Shemesh, M. \& Hansel, W. (1975) Stimulation of prostaglandin synthesis in bovine ovarian tissues by arachidonic acid and luteinizing hormone. Biology of Reproduction 13, 448-452.

Spies, H.G., Slyter, A.L. \& Quadri, S.K. (1967) Regression of corpora lutea in pregnant gilts administered antiovine LH rabbit serum. Journal of Animal Science 26, 768-771.

Steel, R.G.D. \& Torrie, J.H. (1980) Principles and Procedures of Statistics. (2nd Edn). McGraw-Hill, Singapore.

Stouffer, R.L., Nixon, W.E. \& Hodgen, G.W. (1979) Disparate effects of prostaglandins on basal and gonadotropin-stimulated progesterone production by luteal cells isolated from rhesus monkeys during the menstrual cycle and pregnancy. Biology of Reproduction 20, 897-903.

Thomas, J.P., Dorflinger, L.J. \& Behrman, H.R. (1978) Mechanism of the rapid antigonadotropic action of prostaglandins in cultured luteal cells. Proceedings of the National Academy of Sciences USA 75, 1334-1338.
Van der Meulen, J., Helmond, F.A. \& Oudenaarden, C.P.J. (1988) Effect of flushing of blastocysts on day 10-13 on the life-span of the corpora lutea in the pig. Journal of Reproduction and Fertility 84, 157-162.

Walker, F.M.M., Patek, C.E., Leaf, C.F. \& Watson, J. (1977) The metabolism of prostaglandins $F_{2 u}$ and $E_{2}$ by nonpregnant porcine endometrial tissue, luteal tissue and conceptuses in vitro. Prostaglandins 14, $557-562$.

Watson, J. \& Maule Walker, F.M. (1977) Effect of prostaglandins $\mathrm{F}_{2 \mathrm{u}}$ and uterine extracts on progesterone secretion in vitro by superfused pig corpora lutea. Journal of Reproduction and Fertility 51, 393-398.

Watson, J. \& Patek, C.E. (1979) Steroid and prostaglandin secretion by the corpus luteum, endometrium and embryos of cyclic and pregnant gilts. Journal of Endocrinology 82, 425-428.

Watson, E.D. \& Sertich, P.L. (1990) Secretion of prostaglandins and progesterone by cells from corpora lutea of mares. Journal of Reproduction and Ferilitity 88, 223-229.

Wiltbank, M.C., Guthrie, P.B., Mattson, M.P., Kater, S.B. \& Niswender, G.D. (1989) Hormonal regulation of free intracellular calcium concentrations in small and large ovine luteal cells. Biology of Reproduction 41, 771-778.

Wiltbank, M.C., Diskin, M.G., Flores, J.A. \& Niswender, G.D. (1990) Regulation of the corpus luteum by protein kinase C. II. Inhibition of lipoprotein-stimulated steroidogenesis by prostaglandins $\mathrm{F}_{20}$. Biology of Reproduction 42, 239245. 